Accepted version april 2021

please cite as: Maria Tullia Galanti \& Barbara Saracino (2021): Inside the Italian Covid-19 task forces, Contemporary Italian Politics, DOI: 10.1080/23248823.2021.1916858

\title{
Inside the Italian Covid-19 task forces
}

\section{By Maria Tullia Galanti and Barbara Saracino}

One of the most novel political developments during the year of the Covid-19 pandemic, was the mushrooming of a significant number of temporary advisory units, referred to by journalists as 'task forces'. Called upon not only to supply knowledge and information but also policy advice, these advisory units attracted considerable media attention. In April, when the lockdown restrictions were still in force, several newspaper articles reported on the explosion in the number of so-called 'Italian style task forces' ${ }^{1}$, and were very critical of the fact that hundreds of 'experts' were appointed to serve them $^{2}$. The curiosity aroused by this development led to the gathering of a large quantity of information aimed at showing the placement of individuals on a sort of map of 'who decides what during the Coronavirus pandemic' (Openpolis 2020). However, there was little information about who the experts were within this network, or what expertise they brought to the decision-making process, though it was clear that there was a lack of information about their work and little transparency. Regarding public opinion, the investigation carried out in April 2020 by Observa showed that Italian citizens were somewhat dissatisfied with the way in which the experts (both members and non-members of the task forces) communicated, revealing among other things that the diversity of opinions among them created confusion (Bucchi and Saracino 2020).

Despite this unusual prominence of task forces and the various experts involved in making decisions about the Covid-19 emergency, there has been no research into the characteristics of these temporary advisory units or the identities of their members. Using the results of a mapping of the national level Covid-19 task forces and their composition carried out between February and October $2020,{ }^{3}$ we shall answer two questions: How were - what for brevity we shall call - Covid-19 task forces structured, and what was the function of these temporary advisory units? Who were the experts that staffed them and what expertise did they bring to them?

Our analysis focuses on the national level and excludes the health and economic task forces that flourished at the regional level. Specifically, we selected task forces using a two-fold criterion: we identified the bodies created with the remit of providing advice to decision-makers, with at least one advisor who could be described as an outside expert. Indeed, these criteria allow us to define the Covid-19 task forces in the Italian case as examples of temporary advisory policy units (Halligan 1995): bodies close to government, with mixed memberships (including scientific experts but also professionals, managers and bureaucrats) among whom a variety of types of expertise can be identified. The Covid-19 task forces thus distinguished themselves from other bodies created during the emergency, not in terms of their composition, but in terms of their remits as bodies advising the government. They were to formulate recommendations for decision-makers using scientific evidence and specialised knowledge and in some cases consulting relevant stakeholders. These types of activity distinguish the Covid-19 task forces from the 'steering committees' (cabine di regia), whose members had coordination and co-decision making roles, sometimes supplanting constitutionally more appropriate decision-making bodies (Baldi and Profeti 2020).

The objective of the mapping exercise was three fold. First, assembling the terms of reference, papers and minutes of the Covid-19 task forces enabled us to identify which of them had actually been active in producing policy recommendations, that is, recommendations for decision-makers based on expert knowledge concerning an issue of public importance. Second, the mapping of the Covid-19 task forces was aimed at investigating the organisational characteristics of these temporary units, asking about their visibility and transparency, and about the functions they performed during the most acute phases of the emergency. Third, the mapping had the objective of identifying the 
Accepted version april 2021

please cite as: Maria Tullia Galanti \& Barbara Saracino (2021): Inside the Italian Covid-19 task forces, Contemporary Italian Politics, DOI: 10.1080/23248823.2021.1916858

members of the task forces and, through their curricula vitarum (CVs), their socio-demographic and professional characteristics, and their connections.

The article is structured as follows. In the next section we use the literature on policy advice and experts to locate the Covid-19 task forces in Italy in the broader debate concerning the role of policy advisory systems (PASs) and experts in the processes of formulating and making decisions. The subsequent section analyses the organisational characteristics of the Covid-19 task forces, highlighting their functions in emergency policy making. The penultimate section analyses the data concerning their individual members and presents a typology based on their characteristics and types of expertise. The concluding section discusses the evidence presented in the preceding sections in light of the literature on the topic and suggests some further avenues for research.

\section{The role of advisory policy units and experts in Italian policy making}

Recent studies have revealed that the policy-making response to the Covid-19 emergency in Italy has been characterised by a limited policy-making capacity and by incrementalism (Capano 2020), as well as by a further weakening of administrative capacities that had already been debilitated by policies of austerity (Di Mascio et al. 2020). However, it is not clear what role experts have played in bringing about this kind of response.

The explosion in the number of expert task forces providing advice to the government during the emergency was a novel development in the Italian case, and also potentially interesting from a comparative perspective. The characteristics of policy making in Italy make the country an especially inhospitable environment for the establishment of advisory units and the consolidation of practices of transmission of expert knowledge. In Italy, the national-level public administration authoritatively described as 'an ossified world' (Cassese 1999) - continues to play a crucial role in several areas of policy, while knowledge concerning the effects of policy is dispersed across several layers of government (Dente 1995 and 1997). Moreover, the system is dominated by a legalistic culture in which empirical evidence is not used as a matter of routine (Regonini 2012 and 2017).

Hitherto, the use of experts in Italian policy making has been studied only in relation to specific categories of experts (Lippi 2012) or specific cases of reform (Pritoni and Galanti forthcoming; Nannicini et al. 2019). There have been no systematic empirical investigations of the PAS, defined as the actors making up an interconnected whole, with a format specific to its sector and jurisdiction, which provides information, knowledge and recommendations to assist the work of decision-makers (Craft and Howlett 2012, 80; Halligan 1995). In this context we can define policy advice as the activity of transmitting to decision-makers expert knowledge (both scientific and nonscientific) concerning policy problems and solutions, carried out by a variety of actors, both within and outside government and the public administration, through a series of activities ranging from the production of scientific knowledge to the consultation of stakeholders (Craft and Howlett 2012; Veselý 2017).

In the comparative literature, PASs - and the role of experts within them - are studied in order to understand both the amount of knowledge available to the policy makers of a given country, and the forms and degree of influence of expert knowledge over policy making. The literature emphasises that the capacity of a PAS to influence decision makers is in some way linked to, among other variables, the proximity or degree of closeness of advisors to decision-makers (Halligan 1995). Among the actors close to government, an increasingly important role is played by (sometimes temporary) organisations established within executives and composed not only of bureaucrats but also of political leaders' staff. Depending on the nature of the administrative system, these bodies have various names, such as ministerial offices or prime ministers' offices or again, policy units, or, indeed, temporary advisory policy units, in the English-speaking systems (Halligan 1995); ministerial cabinets or uffici di diretta collaborazione (literally: 'offices of direct collaboration') or again 
Accepted version april 2021

please cite as: Maria Tullia Galanti \& Barbara Saracino (2021): Inside the Italian Covid-19 task forces, Contemporary Italian Politics, DOI: 10.1080/23248823.2021.1916858

advisory commissions in the continental and Napoleonic systems (Di Mascio and Natalini 2013; 2016). The growing importance of these advisory bodies within government has demolished what in many countries was the monopoly on knowledge of policy exercised by functionaries of the central government machine (Craft and Halligan 2017).

Another trend highlighted by the literature concerns the growing politicisation of PASs, understood both as the growing presence of advisors with political or party backgrounds - so-called partisan advisors (Craft 2015) - and as the increasing inclusion of judgements of a more typically political or partisan kind in the advice given to decision makers. The latter aspect, concerning the growing political colouring, highlights the way in which it is increasingly important in policy advice that the substantive and technical content be accompanied by a procedural and political content (Craft and Howlett 2013), precisely in order to meet the growing needs of legitimation and representativeness as well as effectiveness of governments (Hustedt and Veit 2017; Galanti and Lippi 2018; Veit et al. 2017).

This theoretical framework meshes well with sociological reflections concerning the various functions knowledge and experts can perform in policy making (Weiss 1979), and especially with the distinction between symbolic and instrumental functions (Caselli 2020, 63-65). Symbolic functions have to do with the use of knowledge for the purposes of legitimation, and make it possible to distinguish between political uses (where scientific evidence and argument are used ex post to justify decisions already taken on the basis of other criteria); tactical uses (which involve emphasising collaboration with scientific institutions even though their evidence is not actually used), and the avoidance of responsibility (which draws attention to the way in which purely technical decisions are in fact highly political in that they redistribute values and affect interests) (Boswell 2008). Rational functions, on the other hand, take their point of departure from the Weberian notion of bureaucracies as rational actors and highlight the way in which resources of knowledge are used, through processes led by (knowledge-driven) experts or (problem-solving) policy makers, to resolve problems. While these functions are never performed in a pure way, they nevertheless make it possible to identify a number of ideal-typical experts.

Useful, in this regard, is the classification Caselli $(2020,69)$ has developed on the basis of the work of such scholars as Pielke (2007), Osborne (2004) and Bauman (1987). Focussing less on the motivations than on the 'substance' of the knowledge involved in the relationship between experts and politicians, Caselli distinguishes between the legislator (who produces intellectual and moral truths), the pure scientist (who produces scientific truths), the scientific arbiter (who communicates scientific knowledge regarded as legitimate or credible), the honest broker (who summarises the available knowledge), the supporter of a cause (who pursues a cause), the policy entrepreneur (who pursues a cause and is influential in the decision-making process), the mediator (who coveys ideas aimed at bringing together concepts and social actors), the expert (who producers technical truths) and the interpreter (who translates concepts and ideas so that they are understandable in contexts other than those in which they originated).

In short, both the political science literature on PASs and the sociological literature concerning experts, suggest that an analysis of the temporary policy units established to deal with the emergency, and their memberships, can be interesting from two main points of view.

In the first place, to answer the question of which Covid-19 task forces were actually active during the pandemic and what they produced, it is important to consider whether their establishment was an exceptional event without much impact or influence on government decisions in 2020. In the second place, to answer the question of who the experts appointed during the emergency were, it is interesting to explore their socio-demographic characteristics, as well as analysing where they came from and what kinds of knowledge they brought to the task forces they were members of. 
Accepted version april 2021

please cite as: Maria Tullia Galanti \& Barbara Saracino (2021): Inside the Italian Covid-19 task forces, Contemporary Italian Politics, DOI: 10.1080/23248823.2021.1916858

\section{The Covid-19 task forces: the rise (and decline?) of advisory units}

The main objective of this section is to use the data from the mapping of the Covid-19 task forces, to consider the extent to which they are structured, transparent and visible ${ }^{4}$ in public debate, assuming that in an emergency situation these aspects are relevant for establishing whether the bodies have had an impact on policy making 5 .

In the first place, it is useful to retrace the events that led to the establishment of these bodies in order to highlight their temporary nature. The seven task forces used for the mapping exercise were established between the beginning of February and the end of April 2020, the period corresponding to the first wave of Covid-19 infections in Italy. The first body to be established was the Comitato tecnico-scientifico (Scientific and Technical Committee, Cts), instituted a few days after the declaration of a state of emergency by the World Health Organisation (WHO) and formally constituted by decree no. 371 issued by the head of the Department for Civil Protection on 5 February 2020. The task force for the efficient and rapid use of measures to support liquidity (the task force Liquidità) was instituted on 29 March 2020 by the Ministry of the Economy and Finance (Mef) as an informal coordinating body with a variable membership in collaboration with the Ministry of Economic Development (Mise), the Bank of Italy (BdI), the Italian Bankers' Association (Abi), Medio credito centrale and the Italian export credit agency, Sace. Meanwhile, the task force, Dati per l'emergenza Covid (Data for the Covid Emergency) was instituted on 31 March 2020 by the Minister for Innovation. On 4 April, the undersecretary at the Prime Minister's Office (Pcm) with responsibility for publishing, instituted the Unità di monitoraggio per il contrasto alla diffusione delle fake news relative al Covid-19 (Monitoring Unit to Counter the Spread of Fake News Concerning Covid-19). A few days later, on 10 April, the Comitato di esperti in materia economia e sociale (Committee of Economic and Social Science Experts, Cees), better known as the 'Commissione Colao' (Colao Commission) was set up. The task force Donne per un nuovo rinascimento (Women for a New Revival, Dnr) was created by the Minister for Equal Opportunities on 13 April; and finally, 21 April saw the setting up of the Comitato di esperti presso il ministero dell'Istruzione, or Committee of Experts Within the Ministry of Education (the so-called task force Mir). The recourse to task forces was a distinctive feature of the second Conte government, so much so that a task force for management of the Recovery Fund was also announced but never set up.

[Table 1 about here]

Table 1 shows the main organisational features of the Covid-19 task forces. The units analysed were extremely weak organisationally. Besides being temporary bodies, they had neither their own budgets nor their own staff (with the exception of the Colao Commission which was able to recruit a small number of assistants) and their members were unpaid. With regard to their location within the administrative machine, it is significant that four out of the seven were (directly or indirectly) responsible to the Prime Minister's Office which was the main political decision maker throughout the emergency (Capano 2020): a circumstance that would lead one to assume that they also had a potential influence in terms of decision-making (following Halligan 1995).

The size of the task forces' memberships was highly variable, ranging from the around ten members of the Liquidità and Fake News task forces, to the 74 members of the Dati task force. In terms of their composition it is worth emphasising that the Cts and the Cees took on a significant number of additional female members around the middle of May, following newspaper criticism of the lack of female representation on these committees, bringing their memberships up to 26 and 24 experts respectively. In contrast, official documents show that the criteria used for recruiting to these bodies were quite uniform, and we can place them in three categories: reputation, technical expertise and bureaucratic expertise ${ }^{6}$. 
The remits that can be deduced from the terms of reference instituting them also varied: the provision of consultation and advice in the case of the Cts; guidance and consultation of stakeholders in the case of Cees and the Mir committee of experts; data analysis and evidence-based advice in the case of the Dati and Dnr task forces; mediation, information exchange and advice on implementation mechanisms in the case of the Liquidità task force; data analysis and consultation of stakeholders in the case of the Unit for the Monitoring of Fake News.

It is therefore apparent that with the exception of the Cts, most of these units were created less to provide policy advice based on scientific evidence than to provide practical solutions to difficult problems - such as the reopening of enterprises and schools or the development of tracing equipment - as well as to represent the views of stakeholders. Analysis of the units' outputs (in the form of reports, statements, operational guidance concerning tracing equipment, and strategic documents, some of which were never published by the government) also confirms the impression that the Covid19 task forces were instituted to provide what has been referred to in the literature as short term or cold advice (Craft and Howlett 2012) on practical matters, and to some extent to enable responsibility for unpopular decisions to be shared.

Still more significant are the data concerning the degree of transparency around the task forces, an aspect that reduces the credibility of advisory bodies in the systems of other countries as well. The Covid-19 task forces were rather weak in this respect too. For example, their members' CVs were published only in the cases of three of them: the Cts, Cees, and Dati. Only the members of Cees and Dati were required to declare that they had no conflicts of interest. Moreover, neither the Fake News nor the Mir task forces published their proceedings. Only the Cts published minutes of its meetings on a regular basis and even then only after a lapse of 45 days. At the same time, only the members of the Cts had to sign a confidentiality agreement, as was, indeed, appropriate given the crucial role of this body in the areas of health and civil protection.

Finally, we thought it would be revealing to carry out further analysis to assess the degree of visibility of the task forces in political debate, looking at the government-Parliament arena, and in public debate, looking at the media presence of the bodies' chairpersons. The expectation is that a task force instituted during a period of emergency will in all probability enjoy greater credibility and influence where it is present in debate and especially when the results of its activity are publicly discussed. An initial finding concerns the number of press releases issued by the task forces, which varies significantly from zero in the case of the Mir and Fake News task forces, to 3 for the Cts, Cees and Drn, 8 for Dati and 27 for the Liquidità task force. Together with the Cts, the latter stood out for the large number of parliamentary hearings at which it was represented ( 8 and 5 respectively). Cees and the Mir task force were represented on two occasions, while the Dnr, Dati and Fake News task forces were represented on no occasions. Only the Cts and Cees were summoned by other members of the government (on 2 and 4 occasions respectively), but for most of the task forces this information is unavailable. With regard to the task forces' proceedings, these were in some cases very varied in nature and produced regularly. Examples include the reports, proposals and recommendations annexed to the minutes of the meetings of the Cts; the 26 weekly reports produced by the Liquidità task force, and the 17 documents produced by Dati. In other cases, the only information available is what is contained in their final documents, as in the case of the four documents prepared by the Dnr and the two reports submitted by the Colao Commission, the first of which was a confidential document submitted to the government with operational proposals concerning the lifting of lockdown restrictions on 24 April, the second of which contained a series of proposals concerning the economic revival of a range of sectors, publicly presented on 9 June. Indeed only these two documents together with those of the Cts gave rise to discussion in the national media. The concluding report of the Mir task force, although submitted to the minister, has never been made public. Paradoxically, the chairpersons of the Mir task force and the Cts gave the most interviews to the press ${ }^{7}$ (for a total of 7 interviews). The businessman, Vittorio Colao, who chaired the Cees, gave four interviews, while the chairpersons of the Dnr and Dati gave none. 
In summary, it is apparent that with the exception of the Cts, all these advisory policy units were sporadic, indeed 'exceptional' entities. The remits and the actual results of these task forces do not therefore seem to have been well adapted to the pursuit of instrumental and problem-solving functions through the production of analysis and evidence concerning matters of health, the economy, technology and equal opportunities. Rather, they seem to have had a more symbolic purpose associated with the need for legitimation, useful for engaging with stakeholders in a situation of emergency or for sharing and even shifting responsibility for controversial and unpopular decisions, i.e. for blame-shifting.

\section{Who are the experts of the Covid-19 task forces? From analysis of the curricula vitarum to a suggested typology}

In order to answer the question of who the members of these bodies are, the mapping of the Covid19 task forces was developed by constructing a database of the individuals making them up. This database gathered information concerning a total of 176 individuals. Only two people were members of two different task forces: Silvio Brusaferro, former president of the Istituto superiore di sanità (Italian National Institute of Health, Iss), and Ranieri Guerra, Italian representative at the WHO, both of whom were appointed to the Cts and the Dati task force. Data for a few variables is missing in some cases because the relevant information (such as the date of birth, missing in 33 cases) was unavailable from the CVs that had been placed online.

In what follows we will discuss the main findings arising from univariate analysis of the variables, gender, age, educational qualifications, political affiliation, group membership, institutional affiliation and profession, and we shall use bivariate analysis to show the distribution of the variables across the individual Covid-19 task forces. Finally, we shall use a two-step cluster analysis to develop a typology based on the three different groups of experts found among the task forces' members.

[Table 2 about here]

With regard to gender composition, males predominated, accounting for $66 \%$ of the members, with $34 \%$ being female (Table 2). Considering the task forces individually, we find that the Dnr had an exclusively female membership; the composition of the Mir task force was more balanced, while males were a large majority of the members of the more visible task forces (the Cts and the Liquidità task force) as well as of the Dati task force.

With regard to age, the most heavily represented were those between 51 and 60 years of age (accounting for $41 \%$ ) followed by those aged 61 to $70(27 \%)$ and by those between 41 and $50(22 \%)$ (Table 2). In the case of the Cts, $85 \%$ were between 50 and 70 years of age. In the cases of the Cees Dnr and Liquidità task forces, the modal age category was represented by those aged between 41 and 50. Among members of the Dati task force, those between 41 and 50 accounted for four out of ten, while half the members of the Fake News task force were under 40 years of age.

$77 \%$ of the members had a postgraduate qualification, while $21 \%$ had a degree and $2 \%$ a highschool diploma (Table 2). Looking at the task forces separately, we find that almost all the members of the Cts had a postgraduate qualification, as was also true for the members of the Dnr, Mir and Dati task forces, while those with a degree but no higher qualification represented the modal category among members of the Liquidità task force. In short, task force members were very highly educated.

Not very surprising was our finding concerning the political affiliations of members, obtained by scrutinising their CVs for details of previous political experience (in party, elective and executive 
Accepted version april 2021

please cite as: Maria Tullia Galanti \& Barbara Saracino (2021): Inside the Italian Covid-19 task forces, Contemporary Italian Politics, DOI: 10.1080/23248823.2021.1916858

offices including at a local level). It was possible to establish the existence of prior political involvements for only nine of those in our dataset. In most cases these involvements entailed being a candidate, an executive member of a municipal council, or a local party functionary, predominantly in the parties represented in the second Conte government (the Five-star Movement, the Democratic Party and Italia Viva). Of the nine individuals with previous political experience, three were members of Dnr and two members of the Dati task force. The other four were members of all of the remaining task forces with the exception of Liquidità.

An unexpected finding emerging from analysis of members' CVs is that almost half (49\%) were members of an interest group (Table 3). We used a broad definition, covering academic and professional representative bodies and national and international foundations, as these can often act as pressure groups with the capacity to influence the legislature and the executive. The main objective of our analysis was to establish whether members had multiple group affiliations and if so, how many.

From the CVs of the 85 experts involved in interest groups as members or leaders, almost 300 groups were identified. Table 3 shows the number of groups of which each individual was, or had been, a member. 22 experts were or had been a member of just one group, 18 of two, 10 of three and 10 of four groups. 25 were or had been members of five or more interest groups. The task forces having the largest numbers of members with multiple group affiliations were the Dnr and the Cts, which therefore appear to be the task forces with the largest number of potential outside connections. In contrast, in the cases of the Liquidità, Dati and Fake News task forces, the overwhelming majority of members had no group affiliations recorded in their CVs.

[Table 3 about here]

Another indicator useful for investigating members' proximity to decision makers is their institutional affiliation, which can also be gleaned from their CVs. Table 3 shows the number of institutions for each member. 102 (59\%) had just one affiliation, 49 had two and the remaining 23 had three or more. It is noteworthy that those with just one affiliation were mainly to be found among the members of the Dnr, Mir and Dati task forces.

The CV data revealed that the number of institutions with which members had affiliations came to more than 200. 40 of these institutions appeared more than once. The most frequently appearing institutions were universities (accounting for 30\% of the total), which was hardly surprising given the recent proliferation of fixed-term teaching contracts awarded to practitioners as well as academics. Of greater significance was the presence of private companies $(11 \%)$, and especially of entities $(24 \%)$ belonging to the broad category of institutions of central government, such as ministries (9\%), public companies (6\%), the Prime Minister's office $(5 \%)$ and independent authorities or agencies $(4 \%)$. There was also a significant presence of research institutes $(7 \%)$ and media institutions $(6 \%)$.

[Table 4 about here]

With regard to the professions, our reading of the CVs revealed that only $46 \%$ of the task forces' members practiced one profession only; one out of three practiced two and $20 \%$ three (Table 4). This finding confirms that more than half the members had considerable networking opportunities. The findings arising from our bivariate analyses are even more interesting. Among members of the Cts, the most heavily represented professions were doctors and public-sector managers (a category that includes top-level mangers in central- and local-government administration, the so-called senior 
Accepted version april 2021

please cite as: Maria Tullia Galanti \& Barbara Saracino (2021): Inside the Italian Covid-19 task forces, Contemporary Italian Politics, DOI: 10.1080/23248823.2021.1916858

civil servants). In the Colao Commission there was a prevalence of academics, but public- and private-sector managers were also heavily represented. The latter were also well represented among members of the Dati task force though there was a prevalence of public-sector managers here. The Mir task force presented a mixed picture, with a prevalence of academics, but with a strong presence of teachers, education managers and entrepreneurs. Female professors dominated the Dnr, while the intellectual professions were the category most heavily represented among members of the Fake News task force. Given the significant presence of university professors, we also considered which disciplines were most heavily represented, finding that $31 \%$ of the members were economists or statisticians, $23.5 \%$ worked in the field of medicine, $16 \%$ in law. Less than $10 \%$ were mathematicians, physicists, historians or philosophers, while less than $5 \%$ were industrial or civil engineers, political or social scientists.

\section{[Table 5 about here]}

Using the variables discussed above, we carried out a two-step cluster analysis, which yielded three ideal typical experts among the members of the Covid-19 task forces ${ }^{8}$ (Table 5). The first group consists of men aged between 50 and 60, university graduates, members of two or more interest groups, affiliated to more than one institution, in top-level positions as public- or private-sector managers or entrepreneurs. Given their multiple group memberships and institutional affiliations, we can assume that this first group consists of experts for whom the pursuit of scientific knowledge is not their main activity, but who occupy a central place in professional networks and who can also make contact with decision-makers easily. This profile seems to be similar to the one Caselli (2020, 69) suggests for the category of mediators. This type of expert accounts for $24 \%$ of our population, and for an even larger proportion of the members of the Liquidità task force and the Cts.

The second group consists of women who are below the average age for our population (up to 50 years), with high-school diplomas, without interest-group memberships and only one institutional affiliation, with intellectual professions as teachers or education managers. This profile seems most closely to resemble that of the public administrator, with technical expertise in a specific sector relating to the functioning of the public administration. We can trace this ideal type back to the profile of the interpreter, useful for importing the ideas of experts into the sphere of the public administration (Caselli 2020). This group, accounting for $42 \%$ of our population, was the one most heavily represented among members of the Dnr. It accounted for about half the members of the Colao Commission and the Dati and Fake News task forces, and was the one most prevalent among the members of the Mir task force.

The third group corresponds to the ideal type of a man above 60 years of age, very highly educated (with a doctorate or post-graduate degree) with one interest-group membership and one institutional affiliation, with a career as an academic or in the medical profession. This ideal type seems to correspond to the expert who offers scientifically based advice, performing a function that is at one and the same time informative, operational and strategic (Caselli 2020). The scientific experts accounted for 34\% of the task forces' members, and were more heavily represented among the members of the task forces with the higher media profiles, such as the Cts and the Colao Commission. Scientific experts were prevalent, along with the administrator-interpreters, among the members of the Mir task force, while they accounted for no more than $30 \%$ of the members of the Dati, Dnr and Fake News task forces and were in a minority among the members of the Liquidità task force. 


\section{Conclusions}

In this article, we have analysed the Covid-19 task forces with two principal aims. On the one hand, we have explored their structural characteristics in order to understand their purposes and whether they have had any impact on policy making. The (small number of) available data allow us to conclude that these advisory units are weakly structured, not very transparent and on average not very salient in political and public debate, with a number of important exceptions consisting of the task forces with the more technical and specialised remits, such as the Cts and the Liquidità task force. In short, during the second Conte government, the task forces were for the most part temporary advisory bodies, with little influence, created in order to serve the government's legitimation needs and to share responsibility for difficult decisions ${ }^{9}$.

From another perspective, we analysed the CVs of the task forces' members in order to throw light on their socio-demographic characteristics and their social connections, and we described their institutional and professional affiliations in order to understand the nature of the expertise they brought to the policy-making process. This analysis enabled us to establish that the Covid-19 task forces drew upon a wide variety of competences, technical and scientific, but also bureaucratic and, above all, relational. In other words, task force members were very well connected outside the advisory circuit linked to the pandemic, though they had few political involvements. This analysis led us to identify three ideal typical consultants at the time of Covid-19: mediators, interpreters and scientific experts. These three ideal types are associated with the functions performed by the main actors of the PAS: those who perform the function of mediation and representation; those who represent the bureaucracies; those who represent the (in this case, scientific) experts drawn from outside the public administration.

Our findings concerning the distribution of the ideal types across the various task forces, suggest some further avenues of research. In this connection, it seems plausible that the weakly structured task forces with little visibility, among whose members there is a predominance of mediators and interpreters, have had a largely symbolic function, one of legitimation and representation. At the same time, it is plausible to think that the better structured task forces, with greater visibility in public debate, staffed by scientific experts and mediators, had a largely instrumental and technical function, one oriented to problem solving.

\section{References}

Baldi, B. and Profeti, S. (2020), 'Le fatiche della collaborazione. Il rapporto Stato-regioni in Italia ai tempi del Covid-19', Rivista italiana di politiche pubbliche, vol. 15, n. 3, pp. 277-306.

Bauman, Z. (1987), Legislators and Interpreters: On Modernity, Post-Modernity and Intellectuals, Cambridge, Polity; trad. it. La decadenza degli intellettuali. Da legislatori a interpreti, Torino, Bollati Boringhieri, 2007.

Boswell, C. (2008), 'The Political Function of Expert Knowledge: Knowledge and Legitimation in European Union Immigration Policies', Journal of European Public Policy, vol. 15, n. 4, pp. 471488.

Bucchi, M. and Saracino, B. (2020), Scared, Supportive and Confident in Science (but a Little Confused by Expert Communication). Trends and Changes in the Perception of the Pandemic: The New Data from the Science in Society Monitor, https://sagepus.blogspot.com/2020/04/italiancitizens-and-covid-19-one-month.html. 
Accepted version april 2021

please cite as: Maria Tullia Galanti \& Barbara Saracino (2021): Inside the Italian Covid-19 task forces, Contemporary Italian Politics, DOI: 10.1080/23248823.2021.1916858

Capano, G. (2020), 'Policy Design and State Capacity in the COVID-19 Emergency in Italy: If You Are not Prepared for the (un)Expected, You Can Be only What You already Are', Policy and Society, vol. 39, n. 3, pp. 326-344.

Caselli, D. (2020), Esperti. Come studiarli e perché, Bologna, Il Mulino.

Cassese, S. (1999), 'Italy's Senior Civil Service: An Ossified World', pp.55-64 in E. Page and V. Wright (eds), Bureaucratic Elites in Western European States, Oxford, Oxford University Press.

Craft, J. (2015), 'Conceptualizing the Policy Work of Partisan Advisers', Policy Sciences, vol. 48, n. 2, pp. 135-158.

Craft, J. and Halligan, J. (2017), 'Assessing 30 years of Westminster policy Advisory System Experience', Policy Sciences, vol. 50, n. 1, pp. 47-62.

Craft, J. and Howlett, M. (2012), 'Policy Formulation, Governance Shifts and Policy Influence: Location and Content in Policy Advisory Systems', Journal of Public Policy, vol. 32, n. 2, pp. 7998.

Craft, J. and Howlett, M. (2013), 'The Dual Dynamics of Policy Advisory Systems: The Impact of Externalization and Politicization on Policy Advice', Policy and Society, vol. 32, n. 3, pp. 187-197.

Dente, B. (1995), In un diverso Stato. Come rifare la pubblica amministrazione italiana, Bologna, Il Mulino.

Dente, B. (1997), 'Sub-National Governments in the Long Italian Transition', West European Politics, vol. 20, n. 1, pp. 176-193.

Di Mascio, F. and Natalini, A. (2013), 'Analysing the Role of Ministerial Cabinets in Italy: Legacy and Temporality in the Study of Administrative Reforms', International Review of Administrative Sciences, vol. 79, n. 3, pp. 328-346.

Di Mascio, F. and Natalini, A. (2016), 'Ministerial Advisers between Political Change and Institutional Legacy: The Case of Italy', Acta Politica, vol. 5, n. 4, pp. 517-538.

Di Mascio, F., Natalini, A. and Cacciatore, F. (2020), 'Public Administration and Creeping Crises: Insights from Covid-19 Pandemic in Italy', The American Review of Public Administration, vol. 50, nn. 6-7, pp. 621-627.

Galanti, M.T. and Lippi, A. (2018), 'Il policy advice tra relazioni e forme di legittimazione', Rivista Italiana di Politiche Pubbliche, 3, 319-332.

Halligan, J. (1995), 'Policy Advice and the Public Sector', pp.138-172 in B.G. Peters and D.J. Savoie (eds), Governance in a Changing Environment, Montreal, McGill-Queen's University Press.

Hustedt, T. and Veit, S. (2017), 'Policy Advisory Systems: Change Dynamics and Sources of Variation', Policy Sciences, vol. 50, n. 1, pp. 41-46.

Lippi, A. (2012), La politica degli intellettuali, Acireale, Bonanno.

Openpolis (2020), Coronavirus, chi decide durante lo stato di emergenza, https://www.openpolis.it /wp-content/uploads/2020/04/Report_Coronavirus_Le-mappe-del-potere.pdf

Osborne, T. (2004), 'On Mediators: Intellectuals and the Idea Strade in the Knowledge Society', Economy and Society, vol. 33, n. 4, pp. 430-447.

Nannicini, T., Sacchi, S. and Taddei, F. (2019), 'The Trajectory of the Jobs Act and the Politics of Structural Reforms between Counter-Reforms and Ambiguity', Contemporary Italian Politics, vol. 11, n. 3, pp. 310-323.

Regonini, G. (2012), 'Parlamenti analitici', Rivista italiana di politiche pubbliche, vol. 7, n. 1, pp. 33-87. 
please cite as: Maria Tullia Galanti \& Barbara Saracino (2021): Inside the Italian Covid-19 task forces, Contemporary Italian Politics, DOI: 10.1080/23248823.2021.1916858

Regonini, G. (2017), 'Governmentalities without Policy Capacity’, Policy Sciences, vol. 50, n. 2, pp. 163-178.

Pielke, R.A. (2007), The Honest Broker: Making Sense of knowledge in Policy and Politics, Cambridge, Cambridge University Press.

Pritoni, A. and Galanti, M.T. (forthcoming), 'Of Pure Academics and Advice Debutants: The Policy Advisory Roles of Political Scientists in Italy', in M. Brans and A. Timmermans (eds), The Advisory Roles of Political Scientists in Europe, London, Palgrave Macmillan.

Veit, S., Hustedt, T. and Bach, T. (2017), 'Dynamics of Change in Internal Policy Advisory Systems: The Hybridization of Advisory Capacities in Germany', Policy Sciences, vol. 50, n. 1, pp. 85-103.

Veselý, A. (2017), 'Policy Advice as Policy Work: A Conceptual Framework for Multi-Level Analysis', Policy Sciences, vol. 50, n. 1, pp. 139-154.

Weiss, C. (1979), 'The Many Meanings of Research Utilization', Public Administration Review, vol. 39, n. 5, pp. 426-431. 
Accepted version april 2021

please cite as: Maria Tullia Galanti \& Barbara Saracino (2021): Inside the Italian Covid-19 task forces, Contemporary Italian Politics, DOI: 10.1080/23248823.2021.1916858 Table 1. The main organisational features of the task forces analysed

\begin{tabular}{|c|c|c|c|c|c|c|}
\hline \multicolumn{7}{|c|}{ Table 1. The main organisational features of the task forces analysed } \\
\hline Name & Policy topic & Location within administraive machine & Duration & No. of members & Criteria used for rectruiting & Remits \\
\hline Cts & Health & Department for Civil Protection & 5 February 2020 -underway & 26 & $\begin{array}{l}\text { Reputation, technical expertise and } \\
\text { bureaucratic expertise }\end{array}$ & Provision of consultancy and advice \\
\hline Cees & Macroeconomics & Prime Minister's Office & $\begin{array}{l}10 \text { April } 2020 \text { - end of } \\
\text { emergency }\end{array}$ & 24 & Reputation and technical expertise & $\begin{array}{c}\text { Consultancy and consultation of } \\
\text { stakeholders }\end{array}$ \\
\hline Atsk force Liquidità & Macroeconomics & $\begin{array}{c}\text { Ministery of the Economy and Finance } \\
\text { (in collaboration with Mise, Banck of } \\
\text { Italy, Abi, Mcc and Sace) }\end{array}$ & 9 March 2020 -underway & 10 & Bureaucratic expertise & $\begin{array}{l}\text { Intermediation, information exchange } \\
\text { and advice on implementation } \\
\text { mechanisms }\end{array}$ \\
\hline Task force Dati & Technology & $\begin{array}{l}\text { Prime Minister's Office (Minister for } \\
\text { Innovation) }\end{array}$ & \begin{tabular}{|c|}
31 March 2020-31 March \\
2021
\end{tabular} & 74 & Technical expertise & Data analysis and evidence-based advice \\
\hline Task force Fake news & Technology & $\begin{array}{c}\text { Prime Minister's Office (Undersecretary } \\
\text { with reposabillity for publishing) }\end{array}$ & $\begin{array}{l}4 \text { April } 2020 \text { - end of } \\
\text { emergency }\end{array}$ & 11 & $\begin{array}{l}\text { Reputation, technical expertise and } \\
\text { bureaucratic expertise }\end{array}$ & $\begin{array}{l}\text { Data analysis and consultation of } \\
\text { stakeholders }\end{array}$ \\
\hline Task force Mir & Education & Ministery of Education & 21 April 2020 - 31 July 2020 & 18 & Reputation and technical expertise & $\begin{array}{l}\text { Consultancy and consultation of } \\
\text { stakeholders }\end{array}$ \\
\hline Dnr & Civil rights & $\begin{array}{c}\text { Prime Minister's Office (Minister for } \\
\text { Equal Opportunities) }\end{array}$ & $\begin{array}{l}13 \text { April } 2020-13 \text { April } \\
2021\end{array}$ & 13 & Reputation and technical expertise & Data analysis and evidence-based advice \\
\hline
\end{tabular}

Source: Decree of establishment.

Table 2. Socio-demographic characteristics of the task force members

\begin{tabular}{|c|c|c|c|c|c|c|c|c|c|c|c|c|c|}
\hline \multirow[b]{2}{*}{ Name } & \multicolumn{3}{|c|}{ Gender } & \multicolumn{6}{|c|}{ Age } & \multicolumn{4}{|c|}{ Educational qualification } \\
\hline & Male & Female & $\begin{array}{l}\text { No. of } \\
\text { cases }\end{array}$ & $<=40$ years & $\begin{array}{c}\text { Between } \\
41 \text { and } 50\end{array}$ & \begin{tabular}{|l} 
Between \\
51 and 60
\end{tabular} & \begin{tabular}{|l|} 
Between \\
61 and 70
\end{tabular} & $\begin{array}{l}>=70 \\
\text { years }\end{array}$ & No. of cases & $\begin{array}{c}\text { High-school } \\
\text { diploma }\end{array}$ & Degree & $\begin{array}{l}\text { Postgraduate } \\
\text { qualification }\end{array}$ & No. of cases \\
\hline Cts & 20 & 6 & 26 & 0 & 3 & 10 & 12 & 1 & 26 & 0 & 1 & 25 & 26 \\
\hline Cees & 15 & 9 & 24 & 0 & 1 & 9 & 7 & 0 & 17 & 1 & 8 & 15 & 24 \\
\hline Task force Liquidità & 9 & 1 & 10 & 0 & 2 & 4 & 2 & 0 & 8 & 0 & 7 & 3 & 10 \\
\hline Task force Dati & 57 & 17 & 74 & 5 & 17 & 22 & 11 & 0 & 55 & 1 & 13 & 60 & 74 \\
\hline Task force Fake news & 6 & 5 & 11 & 4 & 0 & 2 & 2 & 0 & 8 & 0 & 3 & 7 & 10 \\
\hline Task force Mir & 10 & 8 & 18 & 1 & 3 & 6 & 5 & 1 & 16 & 0 & 3 & 15 & 18 \\
\hline Dnr & 0 & 13 & 13 & 1 & 5 & 6 & 0 & 1 & 13 & 1 & 1 & 11 & 13 \\
\hline All task forces & 115 & 59 & 174 & 11 & 31 & 58 & 38 & 3 & 141 & 3 & 36 & 134 & 173 \\
\hline
\end{tabular}

Note: The last row does not correspond to the column totals because it takes into account the fact that two individuals were appointed to two task forces.

Source: CVs of members of each task force. 
Accepted version april 2021

please cite as: Maria Tullia Galanti \& Barbara Saracino (2021): Inside the Italian Covid-19 task forces, Contemporary Italian Politics, DOI: $10.1080 / 23248823.2021 .1916858$ Table 3. Number of interest groups and reference institutions of task force members

\begin{tabular}{|c|c|c|c|c|c|c|c|c|c|c|c|}
\hline \multirow[b]{2}{*}{ Name } & \multicolumn{7}{|c|}{ Number of interest groups } & \multicolumn{4}{|c|}{ Number of institutions } \\
\hline & None & One & Two & Three & Four & $\begin{array}{c}\text { Five and } \\
\text { more }\end{array}$ & $\begin{array}{l}\text { No. of } \\
\text { cases }\end{array}$ & One & Two & $\begin{array}{c}\text { Three } \\
\text { and more }\end{array}$ & $\begin{array}{l}\text { No. of } \\
\text { cases }\end{array}$ \\
\hline Cts & 9 & 1 & 2 & 1 & 3 & 10 & 26 & 12 & 10 & 4 & 26 \\
\hline Cees & 12 & 4 & 0 & 2 & 1 & 5 & 24 & 14 & 6 & 4 & 24 \\
\hline Atsk force Liquidità & 7 & 2 & 0 & 0 & 0 & 1 & 10 & 3 & 3 & 4 & 10 \\
\hline Task force Dati & 45 & 9 & 6 & 2 & 5 & 7 & 74 & 46 & 19 & 9 & 74 \\
\hline Task force Fake news & 7 & 2 & 1 & 1 & 0 & 0 & 11 & 5 & 4 & 2 & 11 \\
\hline Task force Mir & 7 & 2 & 4 & 3 & 1 & 1 & 18 & 13 & 4 & 1 & 18 \\
\hline Dnr & 2 & 2 & 5 & 1 & 0 & 3 & 13 & 10 & 3 & 0 & 13 \\
\hline All task forces & 89 & 22 & 18 & 10 & 10 & 25 & 174 & 102 & 49 & 23 & 174 \\
\hline
\end{tabular}

Note: The last row does not correspond to the column totals because it takes into account the fact that two individuals were appointed to two task forces. Source: CVs of members of each task force.

Table 4. Distribution of professions reported in CVs by task force

\begin{tabular}{|c|c|c|c|c|c|c|c|c|c|c|c|c|}
\hline Name & \begin{tabular}{|c|} 
Entrepreneu \\
$r$
\end{tabular} & $\begin{array}{c}\text { Private-sector } \\
\text { manager }\end{array}$ & $\begin{array}{c}\text { Public-sector } \\
\text { manager }\end{array}$ & $\begin{array}{l}\text { University } \\
\text { professor }\end{array}$ & $\begin{array}{c}\text { Intellectual } \\
\text { profession }\end{array}$ & Education manager & $\begin{array}{l}\text { School } \\
\text { teacher }\end{array}$ & $\begin{array}{l}\text { Medical } \\
\text { doctor }\end{array}$ & Civil servant & Other & No. of cases & $\begin{array}{c}\text { No. of } \\
\text { answers }\end{array}$ \\
\hline Cts & 0 & 0 & 21 & 15 & 4 & 0 & 1 & 21 & 0 & 2 & 26 & 64 \\
\hline Cees & 1 & 7 & 7 & 13 & 5 & 0 & 0 & 1 & 0 & 1 & 24 & 35 \\
\hline Atsk force Liquidità & 2 & 4 & 10 & 2 & 3 & 0 & 0 & 0 & 0 & 0 & 10 & 21 \\
\hline Task force Dati & 8 & 8 & 31 & 34 & 16 & 0 & 0 & 10 & 6 & 12 & 74 & 125 \\
\hline Task force Fake news & 2 & 1 & 2 & 3 & 9 & 0 & 0 & 1 & 1 & 1 & 11 & 20 \\
\hline Task force Mir & 3 & 1 & 4 & 9 & 2 & 3 & 4 & 2 & 0 & 1 & 18 & 29 \\
\hline Dnr & 1 & 1 & 4 & 5 & 3 & 0 & 0 & 0 & 0 & 4 & 13 & 18 \\
\hline All task forces & 17 & 22 & 77 & 79 & 42 & 3 & 5 & 33 & 7 & 21 & 174 & 306 \\
\hline
\end{tabular}

Note: The last row does not correspond to the column totals because it takes into account the fact that two individuals were appointed to two task forces.

Source: CVs of members of each task force. 
Accepted version april 2021

please cite as: Maria Tullia Galanti \& Barbara Saracino (2021): Inside the Italian Covid-19 task forces, Contemporary Italian Politics, DOI: 10.1080/23248823.2021.1916858

Table 5. A typological proposal from the results of a two-step cluster analysis

\begin{tabular}{|c|c|c|c|}
\hline $\begin{array}{l}\text { Socio-demographic, professional and relational } \\
\text { characteristics }\end{array}$ & GROUP 1: Mediators & GROUP 2: Interpreters & GRUPPO 3: Esperti scientifici \\
\hline Gender & Male & Female & \\
\hline Age & Between 50 and 60 years & Up to 50 years & Over 60 years \\
\hline Edcational qualification & University graduate & With high-school diploma & $\begin{array}{c}\text { With a doctorate or post-graduate } \\
\text { degree }\end{array}$ \\
\hline Number of interest groups & $\begin{array}{c}\text { Member of two or more interest } \\
\text { group }\end{array}$ & Without interest-group membership & $\begin{array}{l}\text { With one interest-group } \\
\text { membership }\end{array}$ \\
\hline Number of institutions & $\begin{array}{l}\text { Affiliated to more than one } \\
\text { institution }\end{array}$ & With one istitutional affiliation & With one istitutional affiliation \\
\hline Professions & $\begin{array}{c}\text { Public- or private-sector manager or } \\
\text { entrepreneur }\end{array}$ & $\begin{array}{c}\text { With intellectual profession, teacher } \\
\text { or education manager }\end{array}$ & Medical doctor or academic \\
\hline$\%$ in the population $($ No. $=174)$ & 24 & 42,3 & 33,7 \\
\hline
\end{tabular}

Note: The first column shows the variables considered in the cluster; the cells show the categories of the variables with the highest percentage for each group. Source: CVs of members of each task force. 
${ }^{1}$ S. Rizzo, 'Task force all'italiana. Per scrivere una relazione mobilitati 76 esperti', la Repubblica, 3 April 2020.

${ }^{2}$ By way of example, we may cite the background article in Il Sole-24 Ore, which identified as many as 15 national and regional level task forces staffed by around 400 experts: M. Perrone, ' 15 task force per combattere il virus: ripartenza a rischio caos', 24 Plus: Il Sole-24 Ore, 19 April 2020.

3 The mapping was carried out within the framework of the PRIN2017 research project, 'Who Advises What, When and How?' Some of the missing information was obtained thanks to collaboration with the research-action project sponsored by the Scuola nazionale di amministrazione: 'Il mestiere del policy advice'. The authors wish to thank the investigators associated with both projects for providing access to their data and are especially grateful to Simone Annaratone and Maria Chiara Cattaneo for their valuable and diligent work as research assistants.

${ }^{4}$ The concept of visibility is used here to indicate the importance of the role played by the task forces in political debate. Visibility is a function of the presence of the task forces and their members in political debate (for example, in Parliament and within the executive) and in public debate (for example, in the media). We wish to emphasise, however, that the concept of visibility differs from the concept of transparency, and also that there is no univocal relationship between visibility and decision-making influence. Indeed, it is obvious that an actor with a high level of visibility in debate may have far less influence over a politician's decision than one without visibility (such as, for example, a close relative or a branch of the state whose work is secret). However, it is equally obvious that in the case of bodies appointed in order to develop policy recommendations, like the Covid-19 task forces, a complete absence of visibility can undermine their credibility and so weaken the impact of their decisions.

${ }^{5}$ The mapping exercise excluded those task forces that were the subject of journalistic discussion but for which it was not possible to locate their terms of reference, or any similar formal document. These included the task forces appointed by the Ministry of Justice to advise on prisons and the judicial system; the environment task force appointed by the minister, Sergio Costa, and the Coronavirus 2019-nCov 19 task force appointed by the Ministry of Health. In addition, we excluded from our analysis the two steering committees with the local authorities and with employers' and workers' representatives set up within the Prime Minister's office, because they were staffed exclusively by politicians and had different remits. All of these entities were included in Perrone's investigative piece, ' 15 task force per combattere il virus: ripartenza a rischio caos', cited above.

${ }^{6}$ By 'bureaucratic', we mean that the criterion for selection of the member derived from his/her affiliation with a bureaucratic organisation involved in policy implementation.

7 This indicator was based on a search of the online archives of Corriere della Sera, la Repubblica, La Stampa and Il Sole-24 Ore, carried out by including the names and surnames of the chairs of the task forces among the key words inserted and noting the resulting occurrences.

${ }^{8}$ Two step cluster analysis can be used with categorical variables and was carried out using Statistical Package for the Social Sciences, SPSS.

${ }^{9}$ At the time of writing, the new Prime Minister, Mario Draghi, had appointed as ministers four of the members of the task forces we have analysed: Vittorio Colao, Enrico Giovannini, Patrizio Bianchi and Roberto Cingolani. It will be interesting to see whether the policy advice they helped to develop will gain relevance in management of the crisis going forward. 